\title{
Metacrangon variabilis Rathbun, 1902 sensu lato (Crustacea: Decapoda: Crangonidae) in the North-West Pacific, and applicability of subspecies rank to marine invertebrate taxa
}

\author{
Vassily A. Spiridonov ${ }^{1}$, Victor V. Petryashov $†$ \\ ${ }^{1}$ Shirshov Institute of Oceanology of Russian Academy of Sciences, Nakhimovsliy Prospekt, 36, \\ Moscow 117997, Russia. E-mail:vspiridonov@ocean.ru \\ ${ }^{2}$ Zoological Institute of Russian Academy of Sciences, Universitetskaya Naberezhnaya, 1, St. \\ Petersburg 199034, Russia.
}

ABSTRACT: Metacrangon variabilis Rathbun, 1902 sensu lato was earlier considered to consist of two subspecies: the nominotypical one from the North-East Pacific, and $M$. variabilis asiaticus (Kobjakova, 1955), occurring in the waters of Kuril and Komandor Islands. Although recently both have been given a species rank, and this status is accepted in World Register of Marine Species (WoRMS). In the present study we report a new record of $M$. varaiabilis variabilis from the western Bering Sea. The type series of $M$. variabilis asiaticus (female holotype from off Shikotan I. and 42 paratypes) along with non-type material was located in the collection of Zoological Institute of Russian Academy of Sciences. They were examined with regard to variation of characters used to distinguish between the two subspecies (or species in the alternative view). Most of characters strongly vary, and only relative size of the middorsal carapace teeth may be used for diagnosing $M$. variabilis variabilis and $M$. variabilis asiaticus. Assuming a likely existence of the contact zone in the distribution of these subspecies in the western Bering Sea, it appears premature to elevate their subspecies rank to species. From cognitive standpoint, such nomenclature act would create a false impression of understanding a complex structure of $M$. variabilis sensu lato. For taxonomic revisions, we recommend to consider marine invertebrate subspecies described by earlier authors on case by case basis, but avoiding to rise their rank to species in the absence of extensive analysis of distribution-related morphological variation, and gene markers data.

How to cite this article: Spiridonov V.A., Petryashov V.V. 2019. Metacrangon variabilis Rathbun, 1902 sensu lato (Crustacea: Decapoda: Crangonidae) in the North-West Pacific, and applicability of subspecies rank to marine invertebrate taxa// Invert. Zool. Vol.16. No.3. P.239-253. doi: 10.15298/invertzool.16.3.05

KEY WORDS: Morphological variation, taxonomic revision, museum collections, species and subspecies ranks, North Pacific, shelf margin - upper slope. 


\title{
Metacrangon variabilis Rathbun, 1902 sensu lato (Crustacea Decapoda Crangonidae) в Северо-Восточной Пацифике и вопросы приложения подвидового ранга к таксонам морских беспозвоночных
}

\author{
В.А. Спиридонов ${ }^{1}$, В.В. Петряшев ${ }^{2} \dagger$ \\ ${ }^{1}$ Институт океанологии им. П.П. Ширшова РАН, Нахимовский проспект, 36, Москва \\ 117997, Россия. E-mail: vspiridonov@ocean.ru \\ 2 Зоологический институт РАН, Университетская набережная, 1, Санкт-Петербург 199034, \\ Россия.
}

РЕЗЮМЕ. Metacrangon variabilis Rathbun, 1902 sensu lato раннее рассматривался как вид, состоящий из двух подвидов: номинотипического из Северо-Восточной Пацифики и M. variabilis asiaticus (Kobjakova, 1955) из района Курильских и Командорских о-вов. В настоящее время они рассматриваются как виды, и такой их статус принят в информационной базе World Register of Marine Species (WoRMS). Новая находка M. varaiabilis variabilis сделана в западной части Берингова моря. Типовая серия M. variabilis asiaticus (голотип — самка из района о. Шикотан и 42 паратипа), а также неизвестный ранее нетиповой материал обнаружены в коллекции Зоологического института РАН. Эта выборка исследована в отношении варьирования признаков, используемых для диагностики данных подвидов (или видов в альтернативном варианте). Большинство признаков подвержены значительной изменчивости, и только относительная величина срединных зубцов карапакса может быть использована, чтобы различить $M$. variabilis variabilis и M. variabilis asiaticus. При весьма вероятном существовании контактной зоны в распространении этих подвидов в западной части Берингова моря повышение их ранга до видового выглядит преждевременным. С познавательной точки зрения такой номенклатурный акт создает ложное впечатление понимания сложной структуры комплекса M. variabilis sensu lato. Для будущих таксономических ревизий, имеющих дело с описанными в прошлом подвидами морских беспозвоночных, мы рекомендуем подходить к каждому случаю индивидуально, избегая повышать ранг до вида, если нет возможности получить данные по генным маркерам и провести анализ морфологической изменчивости на широкой географической основе.

Как цитировать эту статью: Spiridonov V.A., Petryashov V.V. 2019. Metacrangon variabilis Rathbun, 1902 sensu lato (Crustacea: Decapoda: Crangonidae) in the NorthWest Pacific, and applicability of subspecies rank to marine invertebrate taxa // Invert. Zool. Vol.16. No.3. P.239-253. doi: 10.15298/invertzool.16.3.05

КЛЮЧЕВЫЕ СЛОВА: Морфологическая изменчивость, таксономическая ревизия, музейные коллекции, видовой и подвидовой ранги, Северная Пацифика, кромка шельфа - верхняя часть склона. 


\section{Introduction}

The subspecies rank is not commonly used in the modern taxonomy of most marine invertebrates owing to several reasons, first of all problems in understanding species limits and patterns of variability (Winston, 1999). Although earlier authors, particularly those working with marine decapods commonly used a subspecies rank, when describing new taxa of the species group. Russian carcinologists Zinaida Ivanovna Kobjakova $(1936,1955,1964)$ and Vladimir Vladimirovich Makarov $(1935,1941)$ made significant contributions to the knowledge of the decapod crustacean fauna of the North Pacific and the Arctic and introduced several subspecies in the 1930-1950s. Most of their subspecific names have been considered valid but the rank of respective taxa was elevated to species, just on the morphological basis, but not always fully accounting for morphological variability, and without studies of gene markers. As an example we refer to the discussion on the rank of a common and commercially fished species, the Pacific northern prawn Pandalus borealis eous Makarov, 1935 (Squires, 1990; Sokolov, 1997; Komai, 1999). Characteristically in such cases, rank elevation becomes accepted in the World Register of Marine Species (WoRMS, 2019). Here we present another case study on the North Pacific crangonid shrimp Metacrangon variabilis Rathbun, 1902 sensu lato.

The genus Metacrangon was established by Zarenkov (1965) who distinguished it by the possession of submedian teeth on the carapace, laterally flared pleura of the sixth abdominal somite, the short appendix masculina bearing spiniform setae, and the lack of an arthrobranch above the base of the third maxilliped. Subsequent studies indicated this genus to be relatively species rich (43 species) and distributed not only in the cold waters of North Pacific, as supposed originally, but also in the deep water throughout the Pacific (Komai, 2012; Komai et al., 2018). One of the deep-sea North Pacific species, Metacrangon variabilis Rathbun, 1902 was described from Alaska and found to occur at the lower littoral to the upper bathyal zone from the Pribilof Islands to California (Rathbun, 1902, 1904). Makarov (1941) recorded this species in the southwestern Bering Sea (Komandor Islands area; Fig. 1), having mentioned some morphological peculiarities of this material. Kobjakova (1955) briefly described subspecies M. variabilis asiaticus from the Kuril Islands. She also referred to this subspecies the specimens from Komandor Islands and the southwestern Bering Sea earlier recorded by Makarov (1941). Although Zarenkov (1960) reported additional specimens from both the southern Kamchatka shelf margin and the Cape Navarin area (northwestern Bering Sea; Fig. 1), and emphasized morphological overlapping between subspecies of $M$. variabilis variabilis . Komai (2012) elevated the rank of Kobjakova's subspecies and presented a detailed redescription of Metacrangon asiaticus, based on the recent material from the southern Kuril Islands, considered as the topotypic specimens, while the type material remained unavailable for this study. The characters used to distinguish between $M$. variabilis and M. asiaticus are few, while Rathbun (1904: 130) mentioned that there is more variation in $M$. variabilis "than is usual in this genus, perhaps owing to the great bathymetrical range".

The recent collection of Metacrangon variabilis in the western Bering Sea far north of Komandor Islands but also reasonably south of the Cape Navarin (Fig. 1), and finding of relatively numerous original Kobjakova's and Makarov's material in the collection of Zoological Institute of Russian Academy of Sciences make it possible to analyze morphological variation of $M$. variabilis sensu lato along an extensive latitudinal gradient. The purpose of this study is to find out if there is overlapping of diagnostic characters, particularly those proposed by Komai (2012) in the specimens of this taxon collected from about $61^{\circ} \mathrm{N}$ to about $43^{\circ}$ $\mathrm{N}$ (Fig. 1), and if the species or subspecies status should be better applied for its current taxonomic treatment. 


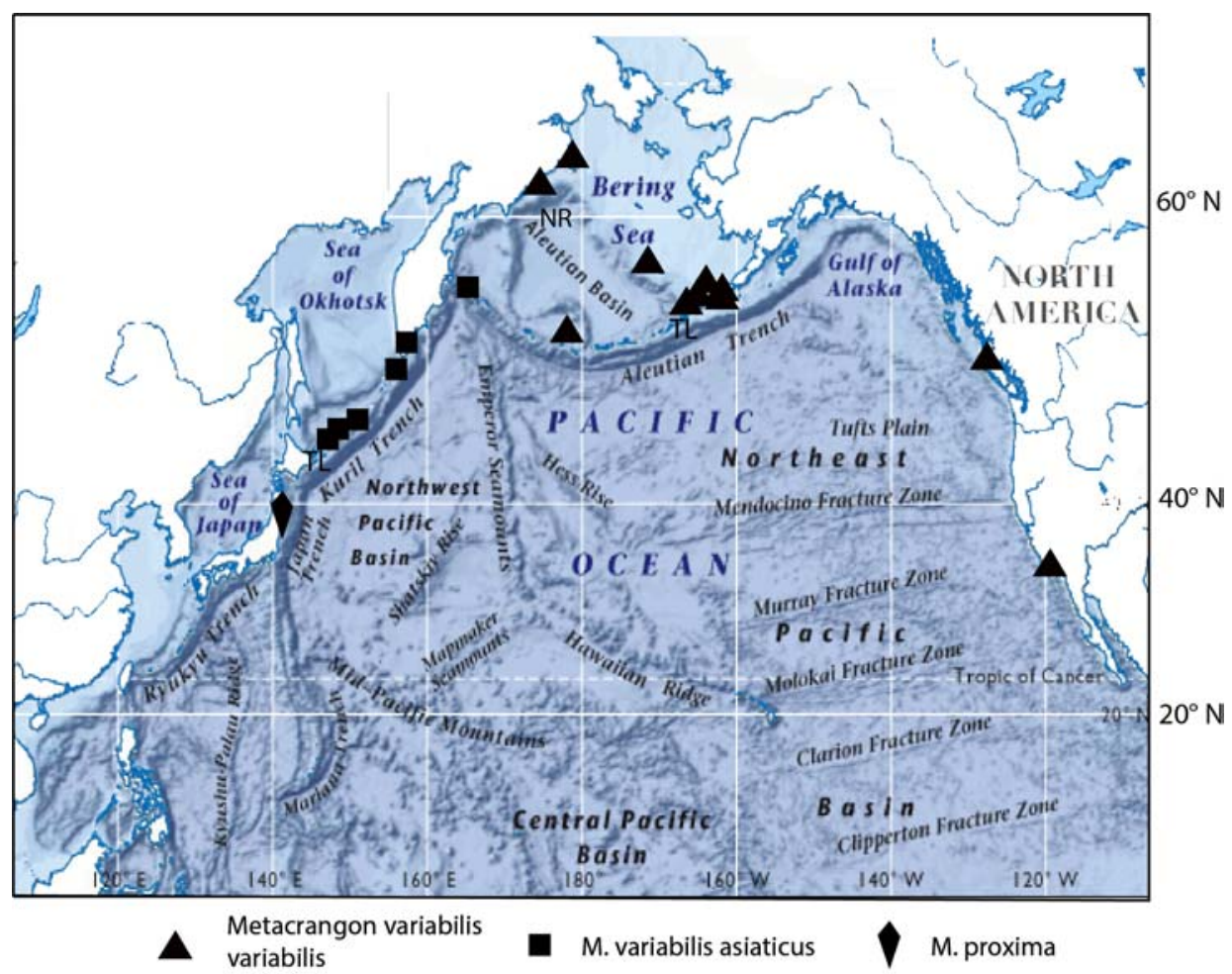

Fig. 1. Distribution of Metacrangon varibilis (Rathbun, 1902) sensu lato and Metacrangon proxima Kim, 2006 based on Rathbun (1902, 1904), Kobjakova (1955), Zarenkov (1960), Butler (1980), Kim (2006) and the present study.

TL - type localities of subspecies of M. variabilis. NR - new record of M. variabilis variabilis. Map is adapted from HRW World Atlas http://hrw.com

Рис. 1. Распространение Metacrangon varibilis (Rathbun, 1902) sensu lato и Metacrangon proxima Kim, 2006 по данным Rathbun (1902, 1904), Kobjakova (1955), Заренкова (1960), Butler (1980), Kim (2006) настоящего исследования.

$\mathrm{TL}$ - типовые местонахождения подвидов $M$. variabilis. NR - новая находка M. variabilis variabilis. Основа картосхемы адаптирована из HRW World Atlas http://hrw.com

\section{Material and Methods}

ABBREVIATIONS. DHI - Department of Hydrobiology and Ichtyology of St. Petersburg University; ICZN - International Code of Zoological Nomenclature; KSE - Kuril-Sakhalin Expedition, 1946-1949; USNM — United States National Museum of Natural History, Washington; ZIN-RAS - Zoological Institute of Russian Academy of Sciences; ZMMU — Zoological Museum of Moscow University.

SAMPLING. Newly collected material originates from the scientific observation programme during shrimp fishery in the Russian Far East.
EXAMINATION OF MUSEUM COLLECTIONS. The collections of ZIN-RAS were inspected for the material studied by Kobjakova (1955, 1958) and Makarov (1941), and other relevant specimens. Practically all specimens of Metacrangon variabilis and $M$. variabilis asiaticus mentioned by these authors are extant in the collection. Besides of this, we found a sample of the specimens also originating from the KSE and identified by Kobjakova as M. variabilis, but neither mentioned in her publications nor registered in the ZIN-RAS collection. This material was stored in former Kobjakova's lab in DHI and was recently transferred to ZIN-RAS. The col- 
lections of ZMMU were inspected as well but no specimens of the species under study were found.

DESCRIPTIONAND MEASUREMENTS. Terminology used in morphological description follows McLaughlin (1980) and Komai (2012), with some changes, i.e. using the term "pleomere" instead of "abdominal somite". The following measurements were taken using a caliper with accuracy $0.1 \mathrm{~mm}$ : carapace length (CL) from the margin of orbit to the posterior margin of carapace; maximum scaphocerite length (ScL), maximum scaphocerite width (ScW), maximum palm (carpus of pereopod 1) length (PL); maximum palm width (PW).

STATISTICAL TREATMENT. All statistical calculations were done using PaST package (Hammer, 2013). For comparison of morphometric charateristics Mann-Whitney and Kolmogorov-Smirnov non-parametric tests were applied.

\section{Systematic account}

Class Malacostraca Latreille, 1802 Order Decapoda Latreille, 1802

Suborder Pleocyemata Burkenroad, 1963 Infraorder Caridea Dana, 1852

Family Crangonidae Haworth, 1825

\section{Metacrangon variabilis variabilis} (Rathbun, 1902)

Figs 2 A, B; 3 A-E; 4 A.

\section{Crangon variabilis Rathbun, 1902: 890.}

Crangon variabilis - Rathbun, 1904: 109, fig. 69. Crago variabilis - Schmitt, 1921: 99, fig. 68.

Sclerocrangon variabilis - Makarov, 1941: 135 (only specimens from Pribilof Islands); Zarenkov, 1960: 347, fig. 4 (partim, specimen from off Cape Navarin).

Metacrangon variabilis - Kim, 2005: 246, fig. 4 (comparison to Metacrangon proxima Kim, 2005); Butler, 1980: 117, unnumbered figure, pl. 5F; Wicksten, 2011: 149 (key), 152 (fig.).

Not Sclerocrangon variabilis - Makarov, 1941: 134; specimens from the Komandor Islands (= Metacrangon variabilis asiaticus Kobjakova, 1955).

MATERIAL. 3 females (ZMMU Ma 3625), northwestern Bering Sea, to the southeast of Cape Navarin, F/V “Stella Karina”, $61^{\circ} 01^{\prime}$ N $176^{\circ} 06^{\prime} \mathrm{W}, 285-300 \mathrm{~m}$, shrimp trawl, 3.06.2014, S.E. Anosov coll.
TYPE MATERIAL. Rathbun (1902) based her original description on a single specimen from Akutan I., the Aleutian Islands, although remarked on a broad distribution of the species. This specimen was figured in her later work (Rathbun, 1904: fig. 69), and this illustration was reproduced by Schmitt (1921: fig. 68). The illustration by Kim (2005: fig. 4) apparently shows the same specimen, the holotype of Crangon variabilis, with a figure caption providing its catalogue number USNM 26703. It is not a reproduction of Rathbun's figure but appears to be an original drawing.

EXTENDED DIAGNOSIS (based on the specimens from the western Bering Sea). Body robust, cephalothorax comprises about one third of total body length. Rostrum quasi-triangular in dorsal view, ascending, dorsal margin laterally straight or convex, slightly overreaching in lateral view antennal teeth (Fig. 2 B), tip in dorsal view subacute or rounded (Figs 2 A, 3 B). Carapace slightly longer than wide; frontal region depressed, middorsal carina extending to posterior fifth of carapace, two subequal middorsal teeth present. Anterior tooth much smaller than rostrum, in epigastric position (arising at anterior fourth of carapace length), slender, subconical, obliquely erect, not reaching base of rostrum, tip acute or rounded; posterior tooth of similar size, directed at similar angle to carapace as anterior one (Figs 2 B, 4 A). Submedian tooth at about midlength of carapace, followed by short, smoothed carina; antennal tooth directed forward in lateral view, acuminate, followed by postorbital ridge, slightly sinuous in lateral view; branchiostegal tooth moderately strong, directed forward in dorsal view, ascending in similar degree to rostrum in lateral view, overreaching dorsodistal lateral angle of antennal basicerite; postorbital angle produced in small, triangular lobe; orbital cleft present; hepatic tooth at somewhat posterior position in relation to anterior middorsal tooth (Figs $2 \mathrm{~A}, \mathrm{~B}$; 3 A, B). A blunt tooth on thoracal sternite 5 in females (Fig. 3 C), a sharp tooth in respective sternite in male, followed by smaller teeth at thoracic sterna 5-7.

Pleomeres 1 and 2 with smoothed middorsal carina; third to fifth somites with smoothed 

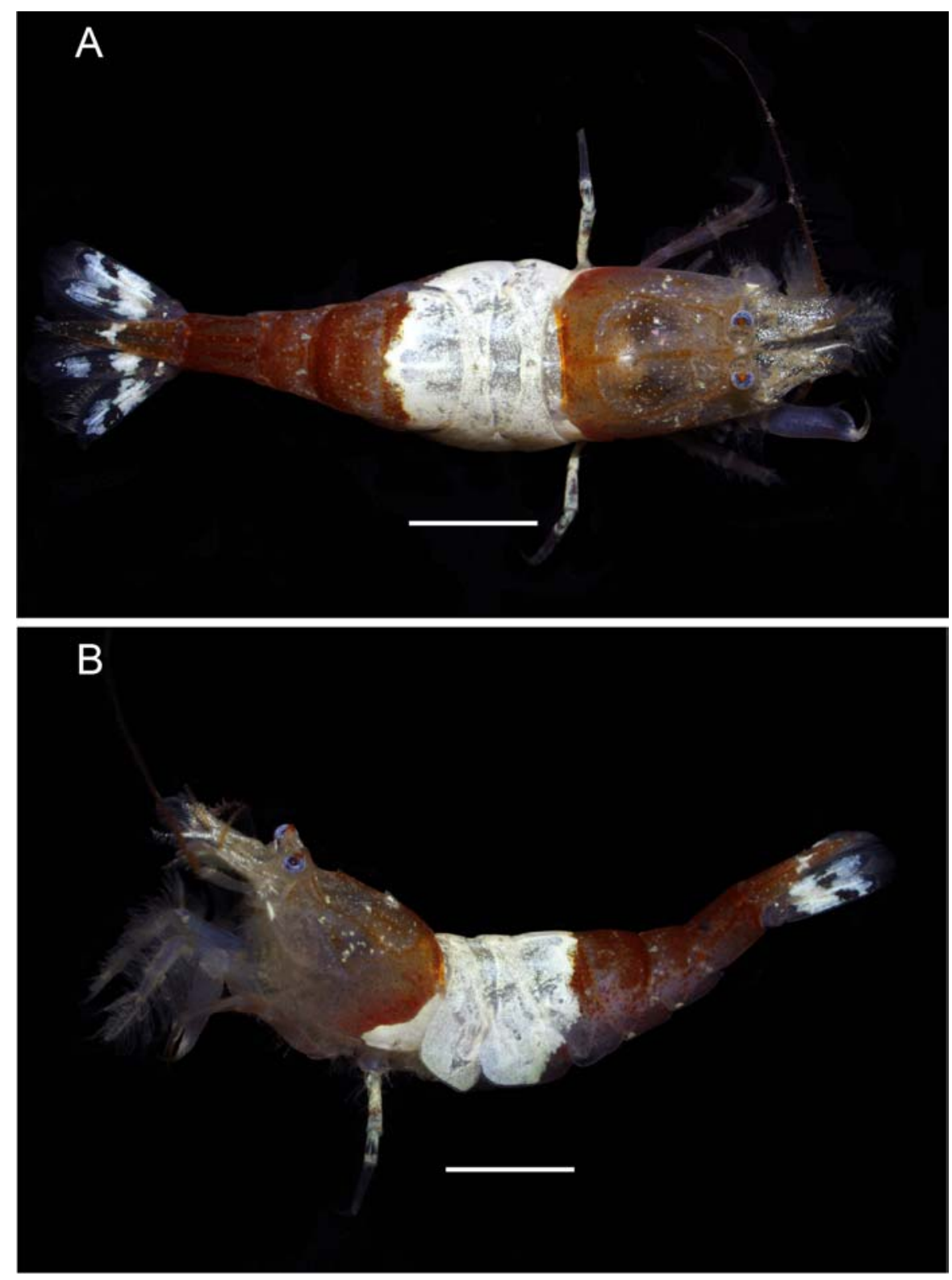

Fig. 2. Metacrangon variabilis variabilis (Rathbun, 1902), western Bering Sea, female (ZMMU Ma 3625, CL $9.4 \mathrm{~mm}$. A - dorsal view; B - lateral view. Scale bar $10 \mathrm{~mm}$. Photo by S.E. Anosov.

Рис. 2. Metacrangon variabilis variabilis (Rathbun, 1902), самка, западная часть Берингова моря, CL 9,4 мм (ZMMU Ma 3625). А — дорсальный вид; В — латеральный вид. Шкала 10 мм. Фото С.Е. Аносова.

middorsal carinae; sixth pleomere with a pair of middorsal carinae, its dorsoposterior margin distinctly concave (Figs 2 A, 3 A). Pleura of first and second pleomeres ventrally strait, on cor- ners rounded. Third somite with obsolete lateral ridge; fourth and fifth somites with distinct lateral ridge. Sixth somite with smoothed submedian carinae; posterolateral process termi- 

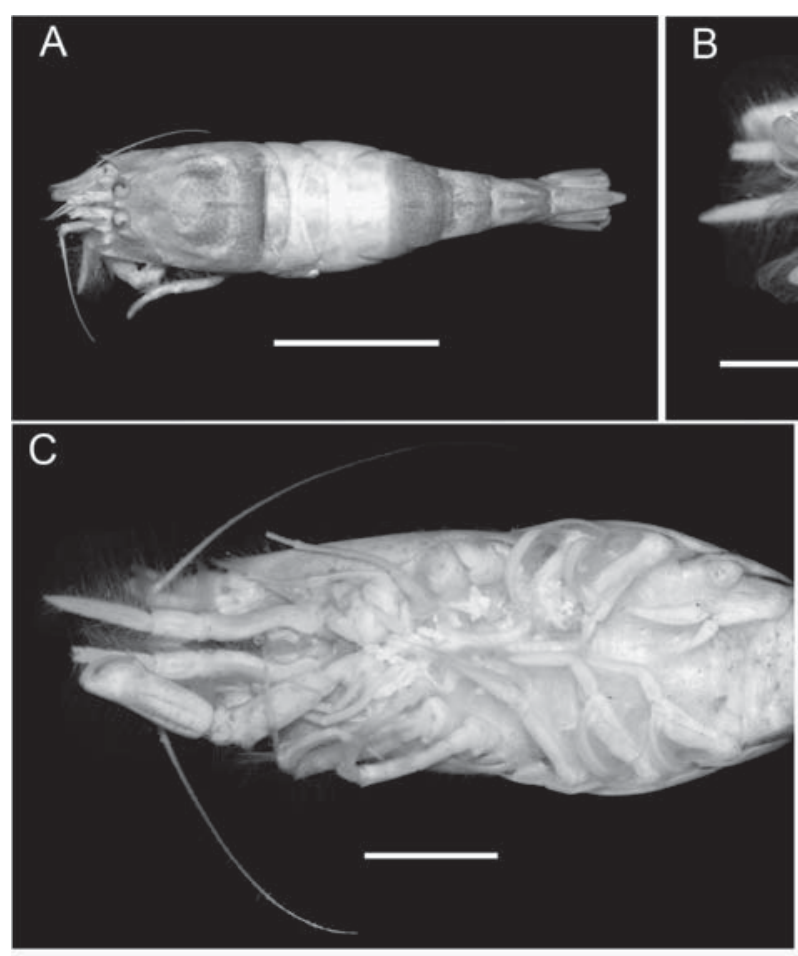
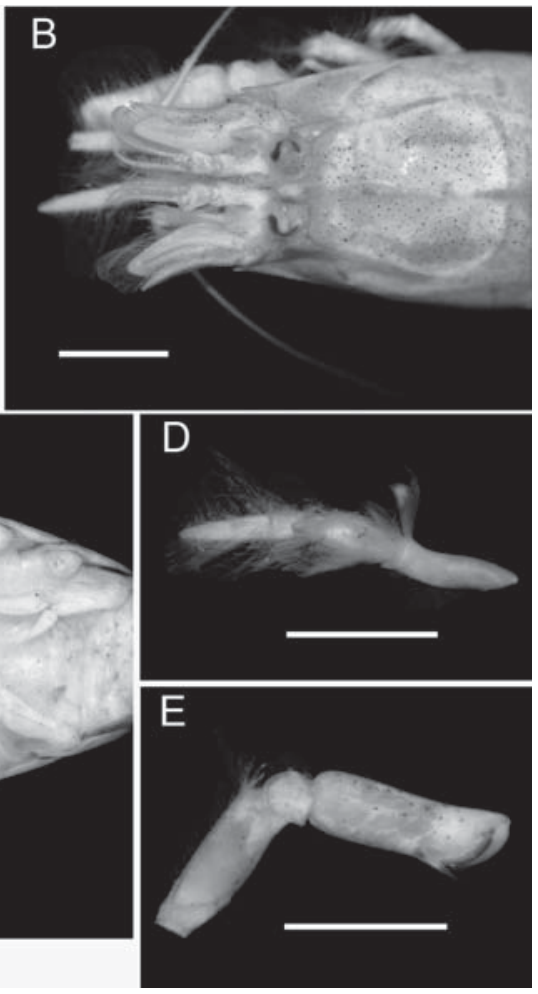

Fig. 3. Metacrangon variabilis variabilis (Rathbun, 1902), female, western Bering Sea (ZMMU Ma 3625), A - female, CL $11.0 \mathrm{~mm}$, dorsal view; B - same specimen as A, anterior part of the body, dorsal view; C - female, same specimen as in Fig. 2, ventral view; D - female, CL $9.0 \mathrm{~mm}$, maxilliped 3, dorsal view; $\mathrm{E}$ - female, same specimen as in Fig. 2, pereopod 1, dorsal view. Scale bar $10 \mathrm{~mm}$ (A), $5 \mathrm{~mm}$ (B-E). Рис. 3. Metacrangon variabilis variabilis (Rathbun, 1902), самка, западная часть Берингова моря (ZMMU Ma 3625), A — самка, CL 11,0 мм, дорсальный вид; В — тот же экземпляр, что на рис. A, передняя часть тела, дорсальный вид; C - самка, тот же экземпляр, что на рис. 2 , вентральный вид; D - самка, CL 9,0 мм, максиллипед 3, дорсальный вид; E - самка, тот же экземпляр, что на рис. 2, переопод 1, дорсальный вид. Масштабная линейка 10 мм (А), 5 мм (B-E).

nating in subacute tooth (Fig. 2 B). Telson about as long as uropods, with a terminal spine and 2 pairs of dorsolateral spines (Fig. 2 A).

Eye stout, exceeding rostrum, 1.5-1.6 times longer than wide, eye width about 0.2 carapace length. Antennular peduncle distinctly overreaching mid-length of antennal scale, stylocerite terminating in subacute tooth, falling short of distolateral process of first segment. Antennal scale short, about 0.45 times as long as carapace and about 2.3-2.5 times longer than wide. Distolateral tooth reaching or slightly overreaching rounded distal margin of lamella (Fig. 2 B). Third maxilliped strongly setose, with ultimate segment gradually tapering distally in distal half, about 4 times as long as than wide; penultimate segment about 2 times as long as wide (Fig. 3 C, D). Palm of first pereopod about 2.9 times as long as wide, lateral and mesial margins faintly sinuous; carpus and merus with 2 distal spines, their lateral spines in ventral and dorsal positions respectively. Second and third pereopods slender, somewhat overreaching antennal scale, chelate and with simple dactylus respectively. Fourth and fifth pereopods stout, with slender naked dactyli, spatulate and subspatulate respectively.

COLORATION. Carapace greyish, semitransparent in anterior part; posterior part, carinae and most spines rosty-orange. Pearly-whit- 

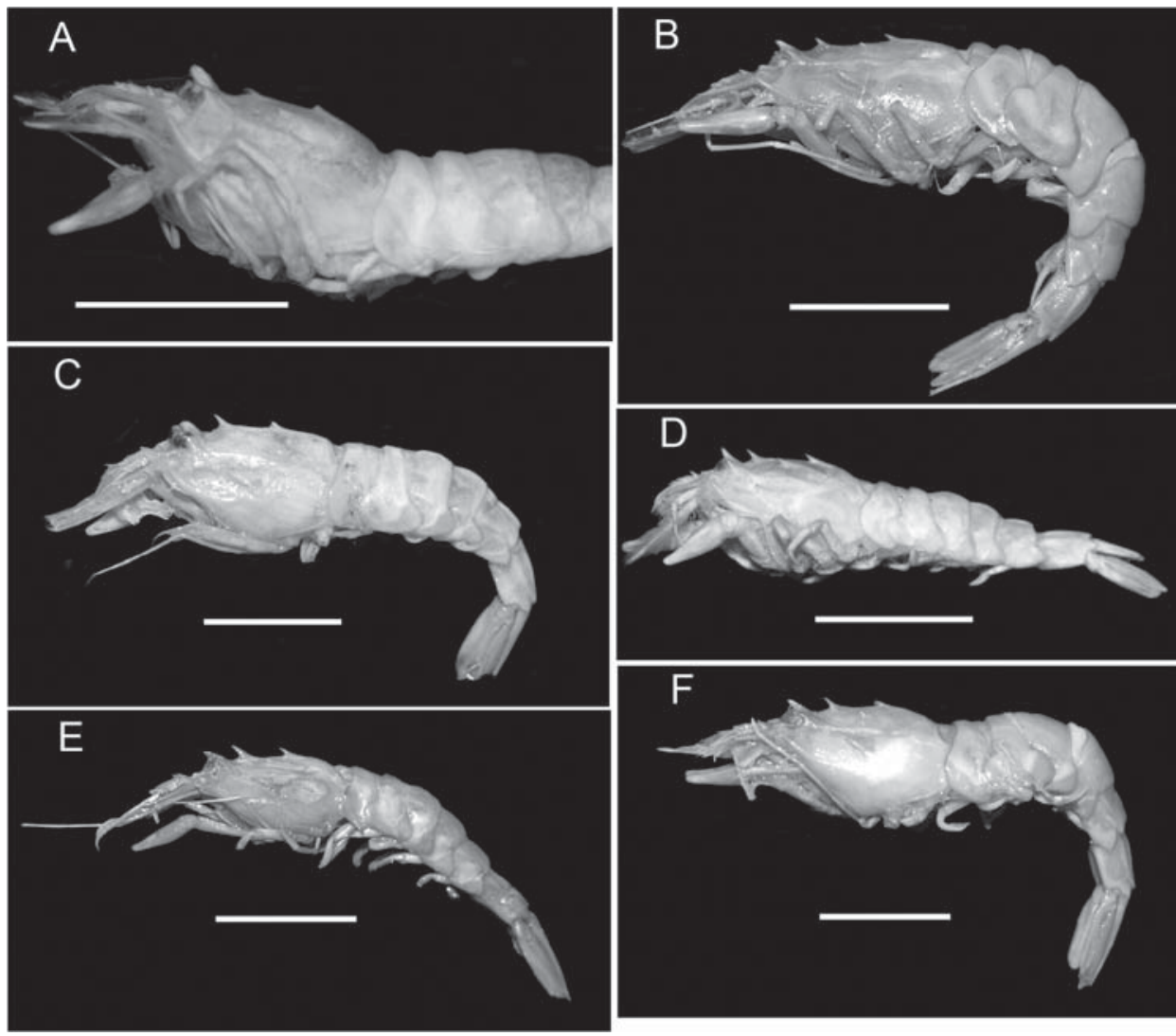

Fig. 4. Lateral view of Metacrangon variabilis sensu lato. A - M. variabilis variabilis, female, western Bering Sea (ZMMU Ma 3625), same specimen as in Fig. 3 A; B - M. variabilis asiaticus (Kobjakova, 1955), female, paratype, Komandor Is. (ZIN-RAS 44742); C - M. variabilis asiaticus, female, paratype, Pacific waters of Iturup I. (ZIN-RAS 36515); D - M. variabilis asiaticus, female, paratype, (ZIN-RAS 53370); E - M. variabilis asiaticus, male, paratype, Komandor Is. (ZIN-RAS 14997); F - M. variabilis asiaticus, female, Komandor Is. (ZIN-RAS 44742). Scale bar $10 \mathrm{~mm}$.

Рис. 4. Metacrangon variabilis sensu lato, вид сбоку. А - M. variabilis variabilis, самка, западная часть Берингова моря (ZMMU Ma 3625), тот же экземпляр, что на рис.3 A; В - M. variabilis asiaticus (Kobjakova, 1955), самка, паратип, Командорские о-ва (ZIN-RAS 44742); C - M. variabilis asiaticus, самка, паратип, тихоокеанские воды о. Итуруп (ZIN-RAS 36515); D - M. variabilis asiaticus, самка, паратип, к СВ от о. Шикотан (ZIN-RAS 53370); E - M. variabilis asiaticus, самка, паратип, Командорские о-ва (ZIN-RAS 14997); F - M. variabilis asiaticus, самка, паратип, Командорские о-ва (ZIN-RAS 44742). Масштабная линейка 10 мм.

ish spots on dorsal carapace and scaphocerites, branchyostegal tooth and posterolateral corner pearly whitish, as well as first two pleomeres. Pleomeres 3-6 and anterior part of telson rostyorange dorsally, with sparse greyish and white dotting, greyish ventrally; tail fan with broad white band with dark spots dorsally. Pereopods bluish-gray, semitransparent; except pereopod
5, which has intensive white spotting (similar to posterolateral corner of carapace) (Fig. $2 \mathrm{~A}, \mathrm{~B}$ ). The specimen from British Columbia was transparent overall, with grayish tinge, fine branching orange-brown and gray-brown chromatophores over body, antennal peduncle, thirds maxillipeds and pereiopods (Butler, 1980: 118, plate $5 \mathrm{~F})$. 
ECOLOGY. The present specimens were caught at depth $285-300 \mathrm{~m}$, where the temperature ranged from 3.4 to $3.8^{\circ} \mathrm{C}$, and commercial concentrations of Pandalus borealis eous Makarov, 1935 were found (S.E. Anosov, pers. comm). In the East Pacific the species occurs between 92 (Rat Islands, western Aleutian Islands) and $1271 \mathrm{~m}$ (Chirikof I., eastern Aleutians) (Rathbun, 1904; Wicksten, 2011). These deepest records were in canyons (Butler, 1980). In Californian waters the species was recorded at about $294 \mathrm{~m}$, so the depth of occurrence does not appear to be latitude-related in spite of significant range extent along the West coast of North America (from about $57^{\circ}$ to about $33^{\circ}$ by latitude).

DISTRIBUTION. Western (Zarenkov, 1960; this study) and eastern (Makarov, 1941; Orr et al., 2014) Bering Sea; Aleutian Islands; British Columbia; off coast of Washington and Oregon, to St. Nicolas I., Channel Islands, central California (Rathbun, 1904; Butler, 1980; Wicksten, 2011).

REMARKS. The present specimens correspond well to the description and illustration of Metacrangon variabilis by Rathbun (1902, 1904), Zarenkov (1960), Butler (1980), Kim (2006) and Wicksten (2011). As shown by Rathbun (1904: fig. 69) and noticed by Wicksten (2011), the anterior mid-dorsal tooth may be somewhat larger than the posterior one. Although it is not the case for the specimens from the western Bering Sea.

Smallest female from the northwestern Bering Sea has characteristic thoracic sternal teeth for males but lacks appendix masculina and possesses a female genital opening at the coxa of pereopod.

Makarov (1941) recorded Sclerocrangon variabilis (=M. variabilis) in the south-western Bering Sea (Komandor Islands) and mentioned some differences from the American specimens. Kobjakova considered the specimens from the Komandor Islands as belonging to $M$. variabilis asiaticus (Kobjakova, 1955) that made them part of the type series of this subspecies (see below). Makarov (1941:135) also mentioned that the specimens from Pribilof Islands $(\mathrm{R} / \mathrm{V}$
"Krasnoarmeets" Stat. 62) are "quite typical". They likely belonged to M. varaibilis variabilis. However, we were not able to locate this material in the ZIN-RAS collection.

\section{Metacrangon variabilis asiaticus \\ (Kobjakova, 1955). \\ Figs 4 B-E; 5 A-C.}

Sclerocrangon variabilis asiaticus Kobjakova, 1955: 236, fig. 2.

Metacrangon asiaticus — Komai, 2002: 63, figs 33$36,42$.

MATERIAL. 1 female ov (CL $10.0 \mathrm{~mm}$ ) (ZIN-RAS 53370, holotype, see below), Pacific waters of Kuril Islands, NE of Shikotan I., R/V “Toporok", KSE, Stat 91, 181 m, 12.09.1949, Sigsbee trawl, Z.I. Kobjakova coll.; 1 female (CL $10.0 \mathrm{~mm}$ ), (ZIN-RAS 53370, paratype), same data as for holotype; 11 females (CL 7.8$9.4 \mathrm{~mm}$ ), 2 females ov (CL $8.8-9.4 \mathrm{~mm}$ ), 3 males (CL 6.8-8.4 mm), 1 sex indet., damaged (ZIN-RAS 36515,paratypes), Pacific waters of Kuril Islands, Iturup I., Kasatka Bay, KSE, R/ V “Toporok" Stat 101, 44²0.8' N 148 24.0' E, 414 m, 14.09.1949, Z.I. Kobjakova coll.; 10 females, 5 females ov, 2 sex indet., damaged (ZIN-RAS 14996, paratypes), Bering Sea, Komandor Islands, south-west of Bering I., R/V

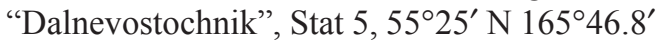
E, 136-200 m, sand, 17.07.1932, Makarov, Ivanov coll. 5 females (ZIN-RAS 44742, paratypes), same data as for ZIN-RAS 14996; 1 male, 1 female (ZIN-RAS 14997), 55²4.7' N $165^{\circ} 44^{\prime}$ E (see Remarks), 200-225 m, sand, 20.09.1932, Makarov, Ivanov coll.

Non-type material. 1 female (CL $8.5 \mathrm{~mm}$ ) (ZIN-RAS 89416), KSE, R/V "Toporok" Stat 19, 1948, P.V. Ushakov coll. 5 females (Cl 8.0$10.6 \mathrm{~mm}), 4$ males $(5.3-7.8 \mathrm{~mm})$ (ZIN-RAS 89418), KSE, Pacific waters of Kuril Islands, off Shikotan I., R/V “Toporok”, Stat 93, 4408.1' N 14757.0' E, 285 m, 13.09.1949, Sigsbee trawl, Z.I. Kobjakova coll. 1 female (CL 11.0 $\mathrm{mm}$ ) (ZIN-RAS 45791), Pacific waters of Kuril Is., east of Paramushir I., R/V “Lebed”, Stat 80, 170-175 m, mud, sand, gravel, 14.07.1954, N.S. Spirina coll.

HOLOTYPE IDENTITY. Kobjakova (1955: 237, fig. 2) published a drawing of an 

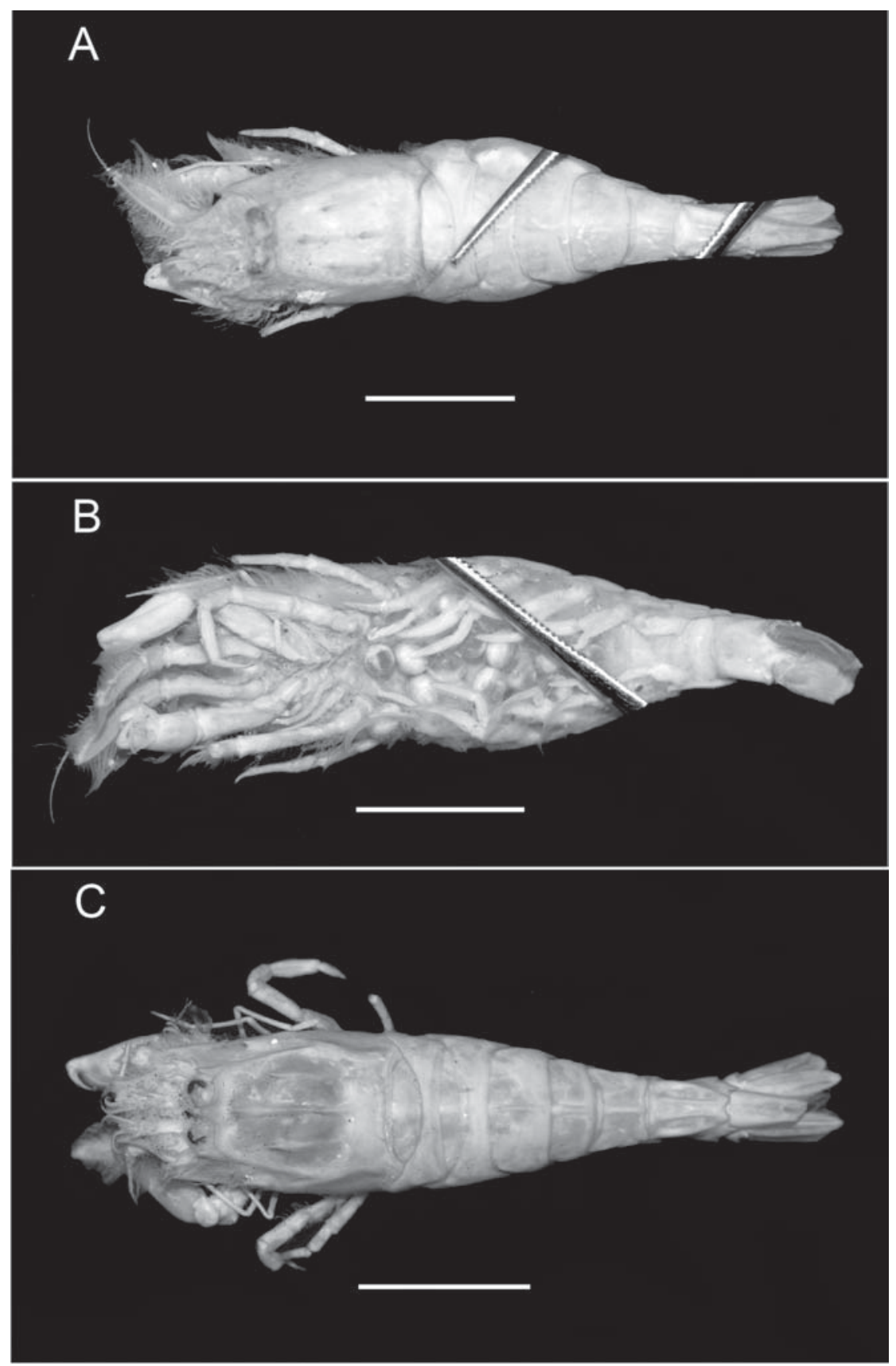

Fig. 5. Metacrangon variabilis asiaticus (Kobjakova, 1955). A - holotype, ovigerous female, NE of Shikotan I. (ZIN-RAS 53370), dorsal view; B - same specimen as A, ventral view; C - paratype, female from topotypic locality (ZIN-RAS 53370), dorsal view. Scale bar $10 \mathrm{~mm}$.

Рис. 5. Metacrangon variabilis asiaticus (Kobjakova, 1955). А - голотип, яйценосная самка, к северовостоку от о. Шикотан (ZIN-RAS 53370), дорсальный вид; В - тот же экземпляр, что на рис. А, вентральный вид; C - паратип, самка из типового местонахождения (ZI N-RAS 53370), дорсальный вид. Масштабная линейка 10 мм. 
ovigerous female and noticed: "Exemplar-type illustrated in fig. 2 was found to the north-east of Shikotan I". There is only one ovigerous female collected together with a similarly-sized nonovigerous female to the north-east of Shikotan I. in the ZIN-RAS collection (catalogue number ZIN-RAS 53370). It corresponds to Kobjakova's illustration. Although the author did not explicitly call it holotype, she stated that only one specimen is "the type". According to ICZN (International Commission, 1999: Article 73.1.1) this specimen (Fig. 5 A, B) must be regarded holotype, and the others mentioned in Kobjakova's (1955) and Makarov's (1941) publication and deposited in the ZIN-RAS collection (42 specimens in total) are paratypes.

DIAGNOSIS. Similar in most characters to Metacrangon variabilis variabilis. Dorsal margin of rostrum obliquely direct, usually straight in lateral view (Fig. 4 B-E). Anterior tooth of middorsal carapace carina obliquely erect, distinctly larger than posterior tooth; posterior tooth directed at lower angle to carapace than anterior one. Hepatic tooth at somewhat posterior position or nearly at same level in relation to anterior middorsal tooth (Fig. 4 A-E). Pleomeres 1 and 2 rounded dorsally or with trace of middorsal carina; third to fifth somites with low, relatively broad, distinct middorsal carinae; Sixth somite with distinct submedian carinae (Fig. 5 A, C). Antennal scale short, about 0.4 times as long as carapace in females and $0.4-0.5$ in males; its length width ratio varies but typically ranges between 2.3 and 2.7.

Palm of first pereopod about 3.0 times as long as wide but ratio significantly varies geographically, lateral and mesial margins faintly sinuous; carpus without distolateral tooth; merus with 1 small dorsodistal tooth. Second and third pereopods overreaching antennal scale. Dactyli of fourth and fifth pereopods spatulate and subspatulate respectively, naked.

Middorsal and antennal teeth in males stronger than in females (Fig. 5 F). Appendix masculina with numerous stiff simple setae.

Ovigerous females with dense setation (compared to non-ovigerous females) of antennae and pereopods (Fig. 5; see also note in Zarenkov, 1960).

VARIATION. As one of distinguishing characters of the subspecies, Kobjakova (1955) mentioned the rostrum to be laterally not convex from behind forward. Indeed, most of the examined specimens have a straight dorsal margin of rostrum in lateral view (Figs. $5 \mathrm{~B}, \mathrm{D}$ ) while in some specimens the rostrum shows slight convexity although to lesser extent than observed in Metacrangon variabilis variabilis (Fig. 5 C). The anterior middorsal tooth in overwhelming majority of cases is distinctly larger than the posterior one (Fig. $5 \mathrm{C}-\mathrm{F}$ ). However, some of the specimens from Kuril Islands have this tooth not much larger than the latter tooth (Fig. 5 B).

Komai (2012) noticed that the distolateral tooth of the antennal scale is more slender and is separated from the distal lamella by a broader notch in the specimens from the Iturup I. compared to M. variabilis variabilis. However we could see much differences when comparing specimens from the type locality (Fig. 5 A, C) to $M$. variabilis variabilis from the western Bering Sea (Figs 2 A, 3 B).

Morphometric characteristics used un the description and the identification key by Komai (2012: 10) show remarkable variation. The linear regression of the scaphocerite length to $\mathrm{CL}$ is presented in Fig. $6 \mathrm{~A}$. With zero intercept the slope equals to 0.439 that roughly corresponds to the ratio 0.4 given by Komai (2012). Females from the type locality off Shikotan I. fall below the $95 \%$ confidence limit of the regression line and have a relatively short scaphocerite (even less than 0.4 CL) while most of females from off the Bering I. are above the confidence limit, about 0.5 CL that according to Komai (2012) is characteristic for $M$. variabilis variabilis. The specimens from off the Iturup I., and M. variabilis variabilis from the western Bering Sea fall over the confidence limits or are at their boundaries (Fig. $6 \mathrm{~A}$ ).

The length/ width ratio of scaphocerite strongly varies (between 2.2 and 2.9), averaging $2.49 \pm 0.033$ for females $(\mathrm{n}=41)$, and $2.55 \pm 0.066$ for males $(n=7)$, showing slight and statistically non-significant negative correlation with $\mathrm{CL}$ 

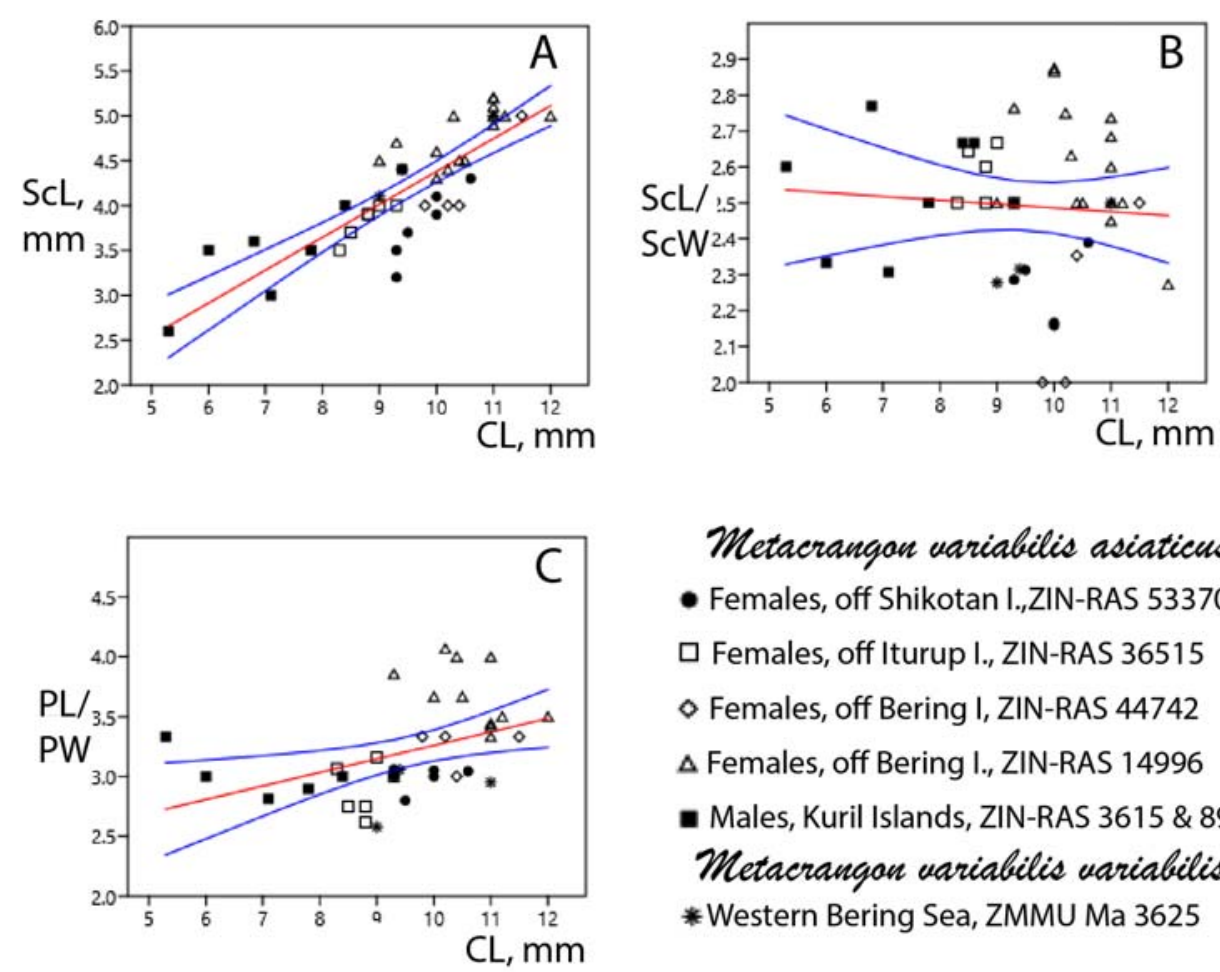

\section{Metacrangan uariabilis asiaticus}

- Females, off Shikotan I.,ZIN-RAS 53370 \& 89417

口 Females, off Iturup I., ZIN-RAS 36515

- Females, off Bering I, ZIN-RAS 44742

$\triangle$ Females, off Bering I., ZIN-RAS 14996

Males, Kuril Islands, ZIN-RAS 3615 \& 89417

Metacrangan variabilis variabilis

*Western Bering Sea, ZMMU Ma 3625

Fig. 6. Morphometric relationships within samples of Metacrangon variabilis sensu lato in the North-West Pacific. A - linear regression (straight line) of the scaphocerite length (ScL) to the carapace length (CL). $\mathrm{ScL}=0.366 \mathrm{CL}+0.715(\mathrm{r}=0.833$, for slope and $\mathrm{r} \mathrm{p}<0.001)$. B - ratio $\mathrm{ScL}$ to scaphocerite width $(\mathrm{ScW})$ in relation to carapace length, correlation and slope coefficients are statistically non-significant. $\mathrm{C}$ - linear regression (strait line) of palm length (PL) to palm width (PW) to carapace length. $\mathrm{PL} / \mathrm{PW}=0.113 \mathrm{CL}+2.13$ $(\mathrm{r}=0.42$; for slope and $\mathrm{r} \mathrm{p}>0.05)$. Curved lines show bootstrapped $95 \%$ confidence interval.

Рис. 6. Морфометрические соотношения в пробах Metacrangon variabilis sensu lato из СевероЗападной Пацифики. A - линейная регрессия (прямая линия) длина скафоцерита $(\mathrm{ScL})$ на длину карапакса (CL). $\mathrm{ScL}=0,366 \mathrm{CL}+0,715$ ( $\mathrm{r}=0,833$, для величины наклона и $\mathrm{r} \mathrm{p}<0,001)$. B - отношение $\mathrm{ScL}$ к ширине скафоцерита $(\mathrm{ScW})$ в зависимости от $\mathrm{CL}$, коэффициенты регрессии и корреляции статистически недостоверны. C - линейная регрессия (прямая линия) отношения длины и ширины клешни (PL/PW) на CL. PL/PW=0,113CL $+2,13$ ( $\mathrm{r}=0,42$; для величины наклона и $\mathrm{r} \mathrm{p}>0,05)$. Изогнутые линии показывают 95\%-ный доверительный интервал, построенный бутстреп-методом.

(Fig. 6 B). The specimens from the type locality off Shikotan I. have mean $\mathrm{ScL} / \mathrm{ScW}$ ratio $2.30 \pm 0.053(\mathrm{n}=6)$. This value is significantly lower than in the specimens from the neighboring locality off Iturup I. (2.67 \pm 0.031 , all tests, $\mathrm{p}<0.01, \mathrm{n}=6$ ), and from the Komandor Islands (2.51 $\pm 0.058, \mathrm{p}<0.01$ for all tests, $\mathrm{n}=18)$. The respective ratio for females of $M$. variabilis variabilis from the northwestern Bering Sea is $2.36 \pm 0.069(n=3)$. It does not differ at statisti- cally significant level from the values for the Shikotan and Komandor Islands samples (neither test) but shows some difference from the Iturup sample of M. variabilis asiaticus (Kolmogorov-Smirnov test value $=0.83, \mathrm{p}=0.05$; but non-significant using other tests).

The palm length to width ration varies from 2.58 to 4.06 and shows a statistically significant positive correlation with CL (Fig. 6 C). This is overlapping with the values for females of $M$. 
variabilis variabilis from the western Bering Sea (mean 2.86 $\pm 0.114 ; n=3$ ). In most of the females from off Shikotan I. and Iturup I. the ratio is less than 3 or equals to it (total mean $2.94 \pm 0.048, \mathrm{n}=12$ ) and falls below the $95 \%$ confidence limit of the regression line. The females from off the Bering I. have a relatively longer palm (PL/PW $=3.56 \pm 0.079)$ with most data being above the confidence limit of the regression line. In males (Kuril Islands) the ratio equals $3.01 \pm 0.089(\mathrm{n}=6)$.

ECOLOGY. From 130-200 or 170-175 to 625-642 m, on sand and gravel. Near bottom temperature at the collection site off Komandor Islands was $0.68^{\circ} \mathrm{C}$, salinity amounted to 33.3 psu (ZIN-RAS catalogue data). The bathymetric range of species distribution along the Kuril Islands generally falls over the distribution of Cold Intermediate water between (roughly 200 $400 \mathrm{~m}$ ) with temperature $1.6-2.5^{\circ} \mathrm{C}$ and salinity 33.3-33.5 psu (Arseniev, Leontieva, 1970; Sirenko, 1994).

DISTRIBUTION. Southern Kuril Islands, Pacific side (type locality of Shikotan Island) (Kobjakova, 1955; Komai, 2012); northern Kuril Islands (Kobjakova, 1958; Zarenkov, 1960); Komandor Islands (Makarov, 1941).

REMARKS. The ZIN-RAS catalogue gives the following position for the lot \# 14997: $52^{\circ} 24.7^{\prime} \mathrm{N} 165^{\circ} 44^{\prime} \mathrm{E}$. This is clearly a mistake because this position corresponds to the abyssal depth. The longitude of the respective Stat 51 of $\mathrm{R} / \mathrm{V}$ "Dalnevostochnik" is practically the same as in Stat 5 where the specimens from lots ZINRAS 14996 and 44742 were collected, the date is three days later, and the depth is $35 \mathrm{~m}$ deeper. It is most likely that the true latitude of Stat 51 is $55^{\circ} 24.7^{\prime} \mathrm{N}$

When studying the sample of Metacrangon variabilis asiaticus from off Iturup I., Komai (2012) has mentioned that a minute denticle between two middorsal teeth is sometimes present. This was not observed in our specimens.

Metacrangon proxima Kim, 2006 was described from the upper bathyal zone $(280-450$ m) of Sagami Bay, Honshu, Japan. Kim (2006) compared it only to $M$. variabilis variabilis although this species is more similar to $M$. variabilis asiaticus, in particular in having stronger teeth of the middorsal carina, the anterior one being largest. Taking into account the variation in the shape of rostrum, orbit, scaphocerite and palm, M. proxima differs from M. variabilis asiaticus only in having the ventral carina of rostrum more obtuse, and not produced anteriorly vs. sharp and produced anteriorly; in the first pair of dorsolateral spines of the telson situated slightly anterior to the midpoint of the telson vs. considerably behind the midpoint of the telson; and in the lateral margin of the stylocerite of antennule being smooth and rounded vs. angular. It appears that $M$. proxima represents further geographical differentiation of $M$. variabilis sensu lato and may also deserve the subspecies rather than the species status. However, currently no records of either $M$. proxima or $M$. variabilis asiaticus are known in the Pacific waters between Shikotan I. and Sagami Bay, and it is unclear whether transitional morphological forms exist.

\section{Discussion}

The biological basis for subspecies as a taxonomic category was first proposed by Semenov-Tianshansky (1910). He emphasized diverse transitions between a single species and its complete separation into two or more species in the course of evolutionary processes. However, for the clarity of nomenclature application Semenov-Tianshansky suggested to apply to these various transitions a single category of subspecies, leaving apart infraspecific categories of earlier authors. Morphological criteria for subspecies are consistent with its biological notion, namely differences in one or few characters with some intergradation in the contact zone. This concept persisted through the century in modified versions, influenced by evolutionary genetic theory (Mayr et al., 1953; Mayr, Ashlock, 1991; Winston, 1999). Currently speciation is seen as a continuous process, where both a strict allopatry and a sympatry associated with ecological divergence may take place (Nosil, 2012). Modern development of molecular 
genetics brought the paradigm of molecular barcode (usually the nucleotide sequence of the mitochondrial cytochrome oxidase subunit I gene), which is used as a marker of evolutionary divergence with common treshholds coinciding to conventional taxonomic ranks (Radulovici et al., 2010; Matzen da Silva, 2011). This concept is complementary to the traditional morphological approach. Although assigning a species rank to the forms, differing in the gene markers but poorly distinguished morphologically becomes a common case (Knowlton, 2000; Bickford et al., 2007). When describing new taxa or redescribing insufficiently documented species/ subspecies taxonomists should not be prescribed to use one or another rank in order to secure the freedom of scientific thought; nevertheless, their decisions must be open to revision.

In the absence of gene markers data, morphology remains the only way to define taxa, hence morphological criteria for subspecies stand. In the case of Metacrangon variabilis sensu lato we could see that the nominotypic subspecies and $M$. variabilis asiaticus are differing by a single character, the relative size of the middorsal teeth. Few other characters were proposed to distinguish between the American and the Asian specimens of $M$. variabilis (Komai, 2012), i.e. the ratio of the scaphocerite length to the carapace length and the morphology of the distolateral spine of scaphocerite. They are variable and do not show hiatus. The present record of $M$. variabilis variabilis in the western Bering Sea and the presence of $M$. variabilis asiaticus at the Komandor Islands make the existence of the contact zone between these subspecies somewhere along the northeastern coast of Kamchatka Peninsula highly possible. Rising the rank of M. variabilis asiaticus to full species would in this case create a false impression that a complicated structure of M. variabilis sensu lato as a lower sublittoral upper bathyal (shelf margin - upper slope) complex is understood. Therefore, a more conservative approach of retaining subspecies status of M. variabilis asiaticus seems preferable until new records will make possible a comprehensive analysis of geographical variability, and obtaining molecular genetic information. As a general recommendation for future taxonomic revisions, we would suggest to consider marine invertebrate subspecies described by earlier authors on case by case basis, but avoiding to elevate their rank to species in the absence of extensive analysis of distribution-related morphological variation, and gene markers data.

\section{Acknowledgements}

We thank Sergei Anosov for collecting specimens and taking photographs of Metacrangon variabilis on board of a fishing vessel and acknowledge the support of MAGADANRYBA group in conducting scientific collection on board F/V "Asanda". We are grateful to Natalia Ivanova for the assistance in working with the ZIN-RAS collection. The studies of the first author was supported by the Russian Foundation for Basic Research (RFBR) project \# 1604-01526 A "Scale and patterns of endemism of the Crustacea Decapoda in the seas of Russia". The contribution of the second author is part of the governmentally funded assignment "Fauna, ecology and biogeography of the invertebrates of the Hydrosphera" \# AAAA-A17-117030310207-3 in ZINRAS.

\section{References}

Arseniev V.S., Leontieva V.V. 1970. [Water masses of the southern part of Kuril-Kamchatka Trench in summer 1966] // Trydy Instituta Okeanologii AN SSSR [Transactions of the Institute of Oceanology of Academy of Sciences of USSR]. Vol.86. P.10-20 [in Russian].

Bickford D., Lohman D.J., Sodhi N., K.L. Ng P.K.L., Meier R., Winker K., Ingram K.K., Das I. 2007. Cryptic species as a window on diversity and conservation // Trends in Ecology and Evolution. Vol.22(3). P.150-155.

Hammer Ø. 2013. PAST: Paleontological Statistics Version 3.0: Reference Manual. Oslo: Natural History Museum. http://folk.uio.no/ohammer/past/past3 manual.pdf (Accessed 03.10.2016).

International Commission on Zoological Nomenclature. 1999. International Code of Zoological Nomenclature. Fourth Edition. London: International Trust for Zoological Nomenclature. $306 \mathrm{p}$.

Kim J.N. 2005. Two new crangonid species of the genus Metacrangon (Decapoda, Caridea) from Japan // Journal of Crustacean Biology. Vol.25. No.2. P.242-250. Kobjakova Z.I., 1955. [New species of Crustacea Decapoda from the southern part of the Kurile-Sakhalin area] // Trudy Zoologicheskogo Instituta Akademii Nauk SSSR (Proccedings of Zoological Institute of Academy of Sciences of USSR) Vol.18. P.235-242 [in Russian]. 
Kobjakova Z.I. 1958. [ Decapod crustaceans (Decapoda) of southern Kuril Islands // Issledovanya Dlanevostichnyh Morei SSSR. 5. Trudy Kurilo-Sakhalinskoi Expeditsii. 1. (Explorations of the Far-Eastern Seas of USSR.Vol.5. Proceedings of the Kuril-Sakhalin expedition. No.1). P.220-248 [in Russian].

Kobjakova Z.I. 1964. [Data on the fauna of Decapoda of the Franz Josef Land and the Spitsbergen regions, and the Greenland Sea] // Trudy AANII [Transactions of Arctic and Antarctic Research Institute]. Vol.259. P.322-329 [in Russian].

Komai T. 1999. A revision of the genus Pandalus (Crustacea: Decapoda: Caridea: Pandalidae) // Journal of Natural History. Vol.33. P.1265-1372.

Komai T. 2012. A review of the western Pacific species of the crangonid genus Metacrangon Zarenkov, 1965 (Decapoda: Caridea), with descriptions of seven new species // Zootaxa. Vol.3468. P.1-77.

Komai T., Chen C., Watanabe H.K. 2018. Two new species of the crangonid genus Metacrangon Zarenkov, 1965 (Crustacea: Decapoda: Caridea) from the Okinawa Trough, Japan // Zootaxa. Vol.440. No.1. P.97-112.

Knowlton N. 2000. Molecular genetic analyses of species boundaries in the sea // Hydrobiologia. Vol.420. P.7390.

Makarov V.V. 1935. Beschreibung neuer DekapodenFormen aus den Meeren des Fernen Ostens // Zoologischer Anzeiger. Bd.109. S.319-325.

Makarov V.V. 1941. [The decapod Crustacea of the Bering and Chukchi Seas] // Issledovanija dalnevostichnikh morei SSSR [Research of Far-Eastern Seas of USSR]. Issue 1. P.111-163 [in Russian with English summary].

McLaughlin P.A. 1980. Comparative morphology of recent Crustacea. San Francisco: W.H. Freeman and Company. $177 \mathrm{P}$.

Matzen da Silva J., Creer S., dos Santos A., Costa A.C., Cunha M.R. et al. 2011. Systematic and evolutionary insights derived from mtDNA COI barcode diversity in the Decapoda (Crustacea:Malacostraca) // PLoS ONE. Vol.6. P.e19449

Mayr E., Ashlock P.D. 1991. Principles of Systematic Zoology. New York: MacGraw-Hill. 475 p.

Mayr E., Linsley E.G., Usinger R.L. 1953. Methods and Principles of Systematic Zoology. NewYork, Toronto. London: McGraw-Hill. 328 p.

Nosil P. 2012. Ecological Speciation. Oxford: Oxford University Press. 280 p.

Orr J.W., Drumm D.T., Hoff G.R, Stevenson D.E. 2014. Species identification confidence in the Bering Sea Slope surveys (1976-2010). AFSC Processed Reports 2014-05. Seattle WA: Alaska Fishery Science Center, NOAA, National Marine Fishery Service. 71 p.
Radulovici A.E., Archambault P., Dufresne F. 2010. DNA barcodes for marine biodiversity: moving fast forward? // Diversity. Vol.2. P.450-472.

Rathbun M.J. 1902. Descriptions of new decapod crustaceans from the west coast of North America // Proceedings of the United States National Museum. Vol.24. No.1272. P.885-905.

Rathbun M.J. 1904. Decapod crustaceans of the northwest coast of North America // Harriman Alaska Expedition. Vol.10. P.1-210.

Schmitt W.L. 1921. The marine decapod Crustacea of California with special reference to the decapod Crustacea collected by the United States Bureau of Fisheries Steamer "Albatross" in connection with the biological survey of San Francisco Bay during the years 1912-1913 // University of California Publications in Zoology. Vol.23. P.1-470, pls 1-50.

Semenov-Tian-Shansky A.P. 1910. Die taxonomische Grenze der Art und ihrer Unterabteilungen. Berlin: Friedländer und Sohn. 24 S.

Squires H.J. 1990. Decapod Crustacea of the Atlantic coast of Canada // Canadian Bulletin of Fisheries Aquatic Sciences. Vol.221. P.1-532.

Sirenko B.I. 1994. [Distribution of benthos in some areas of the continental slope of Kuril Islands] // B.I. Sirenko, S.V. Vassilenko (eds). [The fauna of the continental slope of the Kuril Islands. Based on collections of the 33th Cruise of R/V "Odissey"]. Explorations of the fauna of the seas. Vol.75(83). St. Petersburg: Zoological Institute of Russian Academy of Sciences P.5-43 [in Russian].

Sokolov V.I. 1997 [Variability of the Northern prawn Pandalus borealis (Crustacea, Decapoda, Pandalidae)] // Zoologicheskiy Zhurnal. Vol.76. P.281-286 [in Russian].

Wicksten M. K. 2011. Decapod Crustacea of the Californian and Oregonian Zoogeographic Provinces // UC San Diego: Library - Scripps Collection. Retrieved from https://escholarship.org/uc/item/7sk9t2dz Accessed 20.12.2018.

Winston J.E. 1999. Describing species. Practical taxonomic procedure for biologists. New York: Columbia University Press. 518 p.

WoRMS. 2018. World Register of Marine Species. www.marinespecies.org

Zarenkov N.A. 1960. [Note about some decapod Crustacea of the Okhotsk and the Bering Seas] // Trudy Instituta Okeanology. Vol.34. P.343-350 [in Russian].

Zarenkov N.A. 1965. [Revision of the genus Crangon Fabricius and Sclerocrangon G. O. Sars (Decapoda Crustacea)] // Zoologischeskiy Zhurnal. Vol.44. P.1761-1775 [in Russian].

Responsible editor K.G. Mikhailov 